\title{
DE RUINAS Y CRISTALES: UNA POÉTICA DEL TIEMPO EN LOS TEXTOS DE ANÍBAL NÚNEZZ
}

\author{
MARÍA LuCía PUPPO \\ Universidad Católica Argentina \\ Consejo Nacional de Investigaciones Científicas y Técnicas
}

\section{RESUMEN}

Este trabajo propone una lectura de los textos poéticos del salmantino Aníbal Núñez (1944-1987) a partir del estudio de dos de sus imágenes fundamentales, la ruina y el cristal. En el motivo de la ruina coinciden diferentes tradiciones literarias (barroca, romántica, postmoderna) con las cuales dialoga el corpus del siglo veinte, en tanto que los cristales como modelo heurístico remiten al pensamiento estético de Gilles Deleuze. En primer lugar, se plantearán las bases de una «sintaxis del imaginario» en la poesía de Núñez, es decir, de la lógica que gobierna las relaciones de las imágenes reunidas en torno a estas dos metáforas nucleares (Burgos 1982). En segundo lugar, se buscará perfilar el «trayecto antropológico» de las ruinas y los cristales en tanto imágenes dinámicas, que desde el cuerpo del poema se vinculan con las resonancias pulsionales subjetivas y el imaginario del contexto y la tópica social (Durand 1960, 1993). A modo de conclusión, se propondrán algunos lineamientos para definir una poética del tiempo inscripta en los textos del autor español.

Palabras clave: Aníbal Núñez, ruinas, cristales, poética del tiempo, poesía española, siglo veinte.

\section{ABSTRACT}

This article offers a reading of the poetical texts of Aníbal Núñez (Salamanca, 19441987) focused on the study of two of its most important images, the ruin and the crystal. In the ruin motif many different literary traditions (Baroque, Romantic, Postmodernist) coincide, establishing a dialog with the corpus of the twentieth century. On the other hand, crystals as a heuristic model refer to Gilles Deleuze's esthetics. Firstly, the analysis will provide the bases of a «syntax of the imaginary» in Nuñez's poetry, accounting for the logic that rules the relations among images gathered around both nuclear metaphors (Burgos 1982). Secondly, it will trace the «anthropologic journey» of ruins and crystals as dynamic images that arise from the poem and reach subjective and social imaginaries (Durand 1960, 1993). In conclusion, some guidelines will be proposed in order to define the poetics of time inscribed in the Spanish author's texts. Century.

Keywords: Aníbal Núñez, Ruins, Crystals, Poetics of Time, Spanish Poetry, Twentieth 


\section{INTRODUCCIÓN}

Aunque su nombre figura en las historias literarias y parte de su obra es incluida en las nuevas antologías del período, Aníbal Núñez (1944-1987) continúa siendo el gran desconocido de la poesía española del último tercio del siglo veinte. Durante años la dificultad para conseguir sus textos, muchos de ellos sometidos a ediciones mutiladas y efímeras, convirtió a los lectores del poeta de Salamanca en una especie de secta o círculo de iniciados (Rodríguez de la Flor 1997). Luego la muerte precipitada interrumpió la obra y consolidó el mito de Aníbal; se multiplicaron las reseñas y las ediciones póstumas (Nicolás 1997). Cuando en 1995 aparecieron los dos volúmenes de Hiperión que recogen y ordenan su obra poética dispersa, la iniciativa fue celebrada en los medios más importantes, aunque todavía son escasos los estudios críticos que la abordan en profundidad. Hoy se sabe que los conceptos generales que se aplican a otros poetas de su generación no rigen para la poesía de Núñez, que se distancia en muchos aspectos de la estética de sus coetáneos, los «novísimos».

El universo poético del salmantino exige un estudio aparte, que llegue a internarse en las complejidades formales y semánticas de los textos y que logre avanzar en el intrincado laberinto de referencias y alusiones. Con el fin de ahondar en la tarea iniciada por algunos estudios señeros (AA.VV. 1987, Casado 1999, Valente 1994), este trabajo propone una lectura de los textos poéticos de Núñez como macrotexto, siguiendo un hilo de Ariadna que ellos mismos ofrecen, la continuidad de las imágenes de la ruina y el cristal. Ambas imágenes resurgen de libro a libro con la constancia de una clave alegórica, pero ninguna de ellas posee una significación unívoca. Operan como núcleos metafóricos en torno a los cuales se reúnen otros grupos o familias de imágenes. En el caso de la ruina, el espacio abandonado a merced de la naturaleza favorece la profusión de vegetales y animales, así como la aparición súbita de visitantes, dueños, antiguos moradores y fantasmas. Alrededor de los cristales se multiplican los juegos de luz, las imágenes reflejadas en el agua o el espejo y los avatares de la mirada.

Por un lado, se plantearán las bases de una «sintaxis del imaginario» en la poesía de Núñez, es decir, de la lógica que gobierna las relaciones de las imágenes, en este caso presididas por las metáforas de las ruinas y los cristales (Burgos 1982: 115). Por otro lado, el análisis de la distribución sintagmática de las imágenes se complementará con el abordaje desde el punto de vista diacrónico y paradigmático, en tanto y en cuanto éstas remiten a diferentes tradiciones literarias y modelos epistemológicos con los cuales dialoga el corpus del siglo veinte. En última instancia el objetivo es deslindar el «trayecto antropológico» de la ruina y el cristal en tanto imágenes dinámicas, que cumplen con el circuito que va de la marca lingüística del 
poema a las resonancias pulsionales subjetivas y su impacto en el contexto y la tópica social (Durand 1960, 1993: 38). Tangencialmente nuestro análisis abordará otros aspectos centrales de la poesía de Núñez, tales como la relación entre clasicismo y contemporaneidad, la distancia del sujeto poético, el estatuto del poema y el problema de su supuesto hermetismo. A modo de conclusión, se propondrán algunos lineamientos para definir una poética del tiempo inscripta en los textos del autor español.

\section{El IMAGINARIO DE LA RUINA: TRADICIÓN Y POSTMODERNIDAD}

El tópico de la ruina atraviesa la literatura de Occidente desde la Antigüedad hasta nuestros días. Aunque eran frecuentes las descripciones de edificios de Roma o Constantinopla en las guías para peregrinos o en los relatos de los viajeros medievales, la poesía de las ruinas puede ser considerada como un subgénero que data al menos del Renacimiento y emerge en las literaturas europeas en el siglo diecisiete (McHale 1999: 251) ${ }^{1}$. En el ámbito anglosajón el auge de los cementerios y las ruinas góticas se produjo bien entrada la segunda mitad del siguiente siglo, a partir de poemas que anunciaban la sensibilidad romántica como «Night Thoughts» de Young y «Elegy written in a Country Churchyard» de Thomas Gray. En el siglo diecinueve el motivo se volvió una constante: el paisaje se fusiona con los restos de la Abadía de Tintern en un poema de Wordsworth, la urna griega plantea el problema de la belleza inmutable para Keats, y Poe imagina una ciudad de «torres comidas por el tiempo» (Auden 1978), que recuerda a las escenas pintadas por Constable y Friedrich, donde una naturaleza hostil o fantasmagórica rodea las ruinas lejanas (Wiedmann 1986: $140,154)$.

En cambio en la tradición hispánica la impronta más fuerte es anterior, pues data del barroco, un período en el cual las imágenes provenientes de la mitología y las ciudades antiguas lograron expresar un patetismo inédito hasta entonces. Mientras el poema de Lope lamenta la caída de «la Troya de mi alma», Góngora recurre a Cartago para afirmar la «brevedad enga-

\footnotetext{
${ }^{1}$ Dada la extensión de este trabajo, es imposible sintetizar o citar en su totalidad la profusa y valiosa bibliografía acerca del motivo de la ruina en el imaginario occidental. Sólo destacamos los estudios de Helfer (2003), Lévy (1981), Liuzza (2003) y Znojemská (1998), dedicados a las literaturas en lengua inglesa de los siglos XVII y XVIII; los trabajos de Brennan (2004), Kennedy (2002), Siegmund (2002) y Thomas (2003), centrados en la tradición romántica de la ruina; los análisis de Ferri Coll (1999), Lara Garrido (1980), López Bueno (1988), Pardo Pastor (2002) y Profeti (2003), que tratan el tópico en el Siglo de Oro español; y asimismo las propuestas de Ciplijauskaité (1999), Deshoulières (2000), Parrinder (2002) y Reijen (1992), que incursionan en la pervivencia del motivo en textos del siglo $\mathrm{xx}$, donde es frecuentemente asociado con el subgénero ciencia ficción o con el discurso postmoderno en general.
} 
ñosa de la vida», y Quevedo evoca «la Roma gloriosa del pasado» para enfatizar el contraste con el presente mediocre. El desengaño barroco se tiñe de mayor dolor cuando la reflexión versa sobre la decadencia del propio terruño («Miré los muros de la patria mía») y en ese caso, como lo señaló Walter Benjamin (1998), la ruina es una alegoría que concretiza el cambio histórico. A partir de entonces, la continuidad de la ruina como tópico barroco, romántico, noventayochista y decadente (Casado 1999: 60) se prolonga a lo largo del siglo veinte, a través de textos paradigmáticos como The Waste Land de T. S. Eliot, Alturas de Macchu Pichu de Pablo Neruda o el Himno entre ruinas de Octavio Paz.

Todos estos antecedentes de algún modo son convocados en la poesía de Aníbal Núñez, donde la ruina es un motivo omnipresente y, en palabras de Francisco Freire Jorge, una «metáfora terrible del doloroso declinar» (1987: 296). En su libro sobre las poéticas del autor salmantino, Miguel Casado señaló la importancia del tópico, que marca la incursión en un espacio «patrimonio de unos pocos», donde ocurre una «ruptura del hábito» (1999: 170). El sujeto poético de Núñez conoce el arte de la ruina «diaria, imperceptible, callada», que «preexiste a la ruina misma: es un sistema anterior, infiltrado en la inutilidad de toda lucha» (170).

Los poemarios de Núñez más significativos para el estudio de esta metáfora son los cuatro últimos, Alzado de la ruina (1974-1981)2 ${ }^{2}$, Cuarzo (1974-79, 1981, 1988), Clave de los tres reinos $(1974-85,1986)$ у Primavera soluble $(1978-85,1992)$, a los que se les suman la plaquette Trino en estanque (1982) y el largo poema Memoria de la casa sin mención al tesoro ni a su leyenda antigua $(1984,1992)$. En cada uno de estos libros, elementos paratextuales como los títulos o determinados signos icónicos apuntan hacia un referente real, en la mayoría de los casos un palacio o monumento de la provincia de Salamanca (Puppo 2005).

Los castros y palacios de Núñez remiten a un repertorio cultural, como ocurre con los poetas novísimos, pero además instauran una serie de modalidades de correspondencia entre espacio y tiempo, constituyéndose de ese modo en un auténtico cronotopo (Bajtin 1970). En los poemas del salmantino se produce una simultaneidad de los planos temporales, puesto que en el espacio de la ruina conviven el pasado derrumbado, el presente de la enunciación y el futuro que enmascara una muerte incipiente. El ámbito cerrado de la ruina, rodeado por altos muros y protegido por puer-

\footnotetext{
${ }^{2}$ De aquí en más citaremos según los siguientes criterios. Con respecto a los poemarios, los números entre paréntesis indican la fecha aproximada de génesis y la fecha de publicación, según lo establecido por F. R. de la Flor y E. Pujals Gesalí, editores de la Obra poética de Aníbal Núñez (Madrid, Hiperión, 1995). En el caso de que hubiera una fecha de reedición del poemario, ésta se incluirá detrás de las anteriores. Con respecto a los poemas citados, todos los números de página corresponden al tomo I de Obra poética.
} 
tas y cerraduras, no encaja en el perfil urbano moderno. Por eso ella representa un «santuario de los que sufren cerco» (251), un espacio olvidado que invita a los marginados y excluidos. Se cumple entonces otra característica del cronotopo señalada por Bajtin, la puesta en evidencia de la modulación de la polifonía social. En torno a la ruina se congregan diferentes actores: los industriales cuya «ruidosa máquina socava» (267), los hombres que juegan a la pelota y a quienes no les llama la atención un muro antiguo (312), la dueña burguesa con su «pelo / de vil veraneante» (335). Frente a ellos el poeta opone su contemplación silenciosa, que reúne dos puntos de vista: la mirada estética y metafísica del que «ve en la ruina la Ruina» (311) y la mirada crítica de quien recuerda que detrás de cada palacio existió y existe un tejido social, donde intervienen aún desposesiones y robos de todo tipo $(313)^{3}$.

En los textos de Núñez se va configurando una tipología, donde cada edificio abandonado se erige con una particularidad que lo vuelve único y lo exime «de la taxonomía» (255). Así es que «Teso de San Cristóbal» presenta «una ruina sórdida» (251), el aleteo de las palomas transforma una casa abandonada en «la ruina celeste» (252) y «Casa Lys» se manifiesta como una «ruina pródiga» (254). Del «palacio cerrado orientado hacia el este» se destaca su «Belleza presunta» (257), en tanto que «Itsasoaren Heriotza» se revela como «imagen difícil», «la escena del pasado muerto» (258). La mansión de Séntice es una villa olvidada (265), las ruinas del Fuerte de la Concepción todavía dan «asolada constancia de su magnificencia» en siglos pasados (265) y la «Morada Quinta» provee un espacio íntimo, donde el poeta y su compañera contemplan

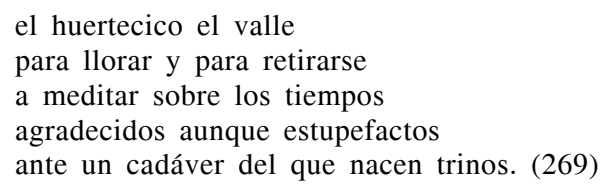

Más adelante, si las ruinas de Alcatrava surgen amenazadas por «el pesado silencio» del valle (305), las de San Bernardo en pleno invierno recuerdan las cuevas de hielo de Kubla-Khan en el poema de Coleridge (311). Y aún prosigue el inventario: En «Visión de Churriguera» el templo lejano se muestra como «modelo inimitable de una ruina / o representación de la soberbia» (312); de «Villa Ludovisi» se mencionan los «jardines con estatuas» (314); al «Columbario» le falta una campana (316). Lo cierto es

${ }^{3}$ El tratamiento de la ruina por parte de Núñez recuerda en este punto el análisis planteado por Raymond Williams en El campo y la ciudad (1973). Detrás de las armónicas y bellas descripciones de la casa solariega inglesa del siglo XVII, Williams supo ver lo que fue excluido de los poemas: el trabajo que originó esas casas y los procesos sociales de los cuales son una culminación (Said 2004: 38-39). 
que tanto para la ruina engalanada («De la magnificencia de estos restos...», 323) como para el castro profanado (355) rige el mismo destino que para la casa de herederos insensatos. A ellos les dice la voz poética: «Remontar no pudisteis la corriente / del deterioro» (334).

La decadencia de la ruina alude mecánicamente al paso del tiempo. Ella es el reino del Ubi sunt, donde sucumbe el tópico horaciano del Exegi monumentum aere perennius: «mas ¿no era / este alto palacio monumento a lo estable?» (256). El paso de los años avanzó con ritmo sosegado pero implacable sobre los edificios; se quebraron las estatuas, se degradaron los oros, se derrumbaron las torres y se perdieron cristales, campanas y estandartes. La «tautología vil del deterioro» avanzó impune, dejando tras de sí «herrumbre o polvo viejo» (389), verdín (115), moho (333), liquen (370) y musgo (254). La naturaleza ha invadido los restos arquitectónicos; «las lluvias continúan sin apresuramientos / la mutación de un torso en hojarasca»; la arenisca se vuelve polvo; el sol se filtra por los artesones (256).

Como «monumento vivo a la caída», en los textos de Núñez la ruina adquiere una belleza singular, que reposa sobre el fragmentarismo y la dispersión:

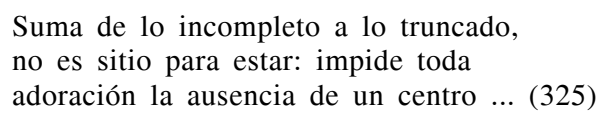

La ruina impone su lenguaje hecho de «signos que interpretar»(324), porque en ella «todo está cerca de ser símbolo» (332). El exterior es descripto con admiración, pero la enumeración de objetos en el interior de la morada — un baúl, una cristalera rota, una pluma, una brújula, libros, muebles, utensilios de cocina- produce en el sujeto poético una fascinación cercana a la del coleccionista. La casa en ruinas es el espacio no habitable pero semióticamente integrador, fuera del cual se volverían «fetiches los objetos rescatados del lote» (335). El pasaje del exterior al interior del palacio está marcado como el ingreso a otro mundo cerrado, donde reina el silencio. Las puertas dan «a lo desconocido, a lo ominoso» (334) y sólo penetran en el misterio de la casa los iniciados. La ruina como cifra hermética permite el acceso únicamente a quienes saben leer sus signos y comprender su mensaje. Blasones y figuras heráldicas, un espejo dorado o «algún detalle gótico» (255) convierten la mansión en una «alegoría a la intemperie», que enfrenta al visitante con «el número justo» y «el Orden de la duda» (256-57). No sorprende entonces que la ruina aparezca como santuario o templo en varias composiciones, ni que ángeles guardianes o incluso un fantasma de aspecto cambiante permitan «que lo espectral habite lo invisible» $(257)^{4}$.

\footnotetext{
${ }^{4}$ El motivo de la ruina opera con el fragmentarismo de los objetos y causa la dispersión de los humanos: así lo muestra tal vez la primera de todas las ruinas, la torre
} 
Ahora bien, esa quietud esencial del edificio abandonado contrasta con el dinamismo - y muchas veces la torpeza - de sus habitantes corpóreos. Maleza y plantas de todo tipo, caracoles, aves, reptiles, un perro y hasta un conejo silvestre se encuentran entre los moradores recientes, aunque los más despreciados por el yo poético son «el profanador» de la ruina (313) y la «propietaria indolente» (329). La ruina altera el equilibrio de la vivienda cotidiana y por lo tanto perturba a los que no captan su belleza difícil:

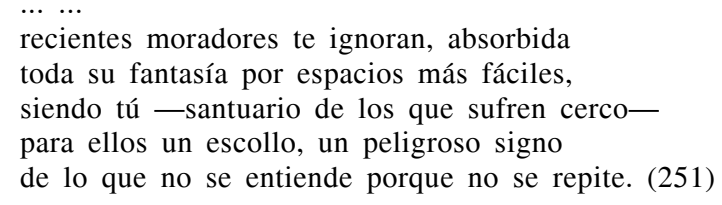

La multiplicidad de perspectivas que se cruzan en los textos de Núñez hace que en ocasiones la voz poética se dirija a la casa como apóstrofe, como ocurre en el poema anteriormente citado. También se da el caso en el que ella asume el rol de sujeto de la enunciación («Soy la mansión de Séntice», 264) y entonces su voz resuena como la de otras aristocráticas antecesoras: el palacete porteño de la novela La casa (1954) de Manuel Mujica Láinez y la mansión habanera del extenso poema Últimos días de una casa (1958), de Dulce María Loynaz. Más allá de la diversidad en los puntos de mira, existe una constante en la figura del poeta, que se presenta a sí mismo como un visitante meditabundo y extasiado, «póstumo paseante por la ciudad ajena» (259). En la visión del poeta, como en el grabado de David Roberts de 1838, Salamanca está rodeada por colinas que se asemejan a «altivas / torres» (273). También la ciudad es una ruina inmensa que tiende «murallas cálidas» alrededor de sus habitantes, hasta convertirse «en planeta ella misma, en orbe aislado» $(260,263$.

«Imán, jaula del sueño, cruce de arquitecturas / y de historias» (255), las ruinas de Núñez se asocian muchas veces con el simbolismo del viaje. La trayectoria física del yo poético, a la que apuntan los datos referenciales, es un índice de su trayectoria vital (Casado 1999: 196). El poeta-viajeroen su provincia apela a la belleza devastada de la ruina, pero le da nuevas significaciones al tópico que van más allá de «la línea ornativa y autoprestigiante de venecianos y neo-neo-clásicos» (Freire Jorge 1987: 295).

Alejándose ya definitivamente de los palacios evocados por los novísimos, las ruinas de Núñez proponen un desmontaje de su propia ficción. El tópico pierde solemnidad cuando el derrumbe de los edificios convive con la invasión vegetal y la cotidianeidad de los moradores y visitantes:

de Babel (Liuzza 2003). Por otra parte, el ambiente fantástico y abstracto de los viejos palacios descritos por Núñez recuerda, en ocasiones, el paisaje futurista de «Las ruinas circulares» de Borges. 
«alguien cultiva champiñón en el cuerpo de guardia» (266). Más que un símbolo elegíaco, las ruinas son para Núñez «un lugar de crítica, de lúcida reflexión» (Nicolás 1997: 12). El poema mismo aparece como un edificio de distintos pisos y niveles, hecho con las ruinas de otros discursos - pastiches fragmentarios- clásicos, barrocos y románticos. La inclusión del léxico arcaizante y el uso insistente del hipérbaton crean un efecto de anacronismo, en tanto que la comunión con el paisaje esquiva la ingenuidad decimonónica. Por ejemplo, el yo poético hace una referencia a la «Ode to the West Wind», de Shelley, pero de un modo nada inocente: «el viento del oeste, / de rara aparición y reputado / como sentimental» (253).

Las ruinas hablan de un presente contaminado por la muerte, de una existencia vacía, al punto tal que en muchas culturas ellas son un símbolo equivalente al de las mutilaciones en lo biológico (Cirlot 1969: 406). Se ha visto en la ruina el objeto que mejor caracteriza al siglo veinte - el siglo del psicoanálisis - porque es un objeto que habla, que cuenta una historia, y que posee, por lo tanto, lenguaje (Wajcman 2004). En uno de sus últimos trabajos dedicado a este tema, Marc Augé ofrece la siguiente definición: «La ruina ... es el tiempo que escapa a la historia: un paisaje, una mezcla de naturaleza y de cultura que se pierde en el pasado y surge en el presente como un signo sin significado» (2003: 110). La ruina nos hace experimentar el tiempo puro, pues está desprovista de su contexto original y su carácter histórico fue limado por la intemporalidad de la naturaleza. Más que relatora de historias, para Augé la ruina es un no-lugar abierto a distintas posibilidades. Si el arte logra preservar la singularidad de la ruina, su belleza radicará en esa vivencia del tiempo que transmite, «conciencia de una carencia, expresión de una ausencia, puro deseo» (116). Pero si la restauración persigue en cambio la espectacularización de la ruina, entonces ella acabará reducida a imagen-simulacro, a un juego de luces sin identidad, diseñado para atraer turistas.

Las ruinas tienen forma de un recuerdo porque se nos presentan en un lugar y un clima propios, configurando una escena (Augé 2003: 87). También en los poemas de Núñez se exponen los resortes de la memoria, que opera con fragmentos de lo vivido. La escritura es la etapa posterior a la visita y la contemplación, en la cual el sujeto manipula esos datos que configuran la escena de la ruina:

\author{
... la memoria \\ aunque tocada, si es precaria, \\ lo es por ser selectiva. Pido al silencio datos, \\ bálsamo a este aire ajeno, perdón a la distancia. (331)
}

El poeta es consciente del límite de su oficio. A fin de cuentas las palabras son también astillas del pasado, ruinas de la experiencia, huellas de lo vivido. 


\section{LAS CARAS DEL CRISTAL O UN MODELO HEURÍSTICO}

En la poesía de Aníbal Núñez asume la enunciación una voz depurada, corrosiva y sin sentimentalismos. Muchas veces la distancia del sujeto poético se prolonga en metáforas donde la interioridad asume un ropaje externo y mineral: «una lágrima seca, cristal de pena» (356), «ese respeto helado que se rompe en cristales / dentro de ti» (355).

Así como se ha estudiado la preeminencia de un imaginario vegetal en los textos poéticos del salmantino (Casado 1999, Puppo 2004a), también se ha señalado la importancia del mineral en tanto «metáfora mística allí donde el yo se anula en las cosas, en su devoción violenta por ellas, y las cosas vienen también a acabarse en el yo» (Rodríguez de la Flor 1987, cit. en Casado 1999: 181). En el universo poético de Núñez, como en el mundo real, existe una continuidad entre el mundo inorgánico y el mundo biológico. El trayecto de su escritura puede resumirse en un verso que alude al triple eje de la existencia, donde se combinan «la avidez del cristal, la piel y el pétalo» (342).

La mineralogía define como cristal a cualquier cuerpo sólido que naturalmente tiene forma poliédrica más o menos regular, como es el caso de ciertas sales, piedras y metales. Hoy la ciencia habla de sistemas cristalinos —cúbico, cuadrático, ortorrómbico, monoclínico, triclínico, hexagonal o romboédrico- L Los cristales presentan propiedades ópticas específicas: transparencia u opacidad, reflexión y refracción, brillo, fluorescencia (BuciGlucksmann 2003). A estos conceptos recurriremos para abordar ciertos aspectos de la compleja arquitectura que conforman los poemas de Núñez. En ellos subjetividad y mineralidad son dos polos antagónicos que sin embargo aparecen unidos, y esa contradicción se suma a otras paradojas propias del cristal, que al mismo tiempo representa mediación y límite, solidez y fragilidad.

En la poética de Núñez la transparencia del cristal se relaciona con el problema de la visión. El cristal de la ventana tiene una función comunicante, pues permite «abrir ... / la mirada a otro júbilo más amplio» (168). Pero ya el Prólogo en verso a Fábulas domésticas (1972), el primer libro del poeta ${ }^{5}$, advierte que «Hay cosas que saltan a la vista, / cabronadas urdida-s-utilmente...» y luego concluye: «Y gafas protectoras, al alcance de todo / bicho viviente, en / nuestra sección menaje del hogar» (45). La parodia del discurso de la publicidad y el tono irónico presentes en este texto inicial apuntan tanto a una dura crítica al consumismo como al rechazo de la mirada culturalmente codificada.

${ }^{5}$ Antes de este poemario, Aníbal Núñez publicó catorce textos en 29 poemas (1967), un volumen firmado también por Ángel Sánchez. 
En toda la poesía de Aníbal hay una recurrencia de verbos implicados en la visión (mirar, contemplar), así como una profusión de colores y juegos de luz. Las artes plásticas constituyen un intertexto constante, en la medida en que los poemas aluden al título de una pintura, a un autor, una técnica o un motivo pictórico: «esta luz difuminada / cambia todo color, lo hace más triste» $(155)^{6}$. La figura del poeta-visitante es asociada a la del espectador, a quien el «júbilo de los ojos» (308) provocado por la belleza del paisaje o la ruina le dejan después «la vista / enriquecida, tibia, más de tierra, más grave» (311).

La predilección por los juegos cristalinos de opacidad y transparencia reaparece en una plaquette póstuma, titulada Cristal de Lorena (1987). El título general reproduce el del primer poema en tres secciones. El sintagma hace referencia a unas láminas de vidrio que utilizaban los cortesanos del siglo XVIII para contemplar el paisaje. Precedentes de los anteojos de sol, los cristales de Lorena recibieron su nombre «de las atmósferas dulcificadas y cálidas que pintaba Claude Lorrain» (Núñez 1995: 385). Como cerrando el círculo que abrían las Fábulas domésticas, se menciona el «óxido de la vida» que va formando

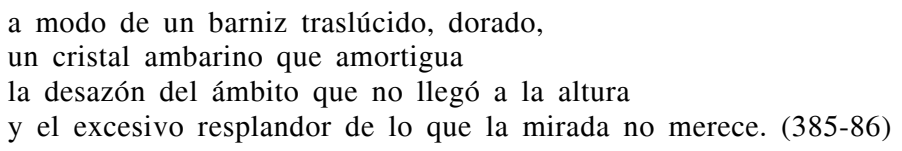

En contraposición, el segundo y último poema de la plaquette se titula «Cristal de Bohemia», que no es otra cosa que «el falso topacio o cuarzo teñido de su color» (388). Un epígrafe de Rimbaud (Assez vu: demasiado visto) adelanta que en este caso el mineral evoca la dureza acumulativa de lo que se ha percibido: «En el fondo del ojo el pasado se agrieta» (388). Pero si es difícil avanzar «sin caer en la trampa / de un código aprendido», la ascesis de la mirada lleva a considerar la vida como un viaje de depuración, como una búsqueda que nunca se acaba:

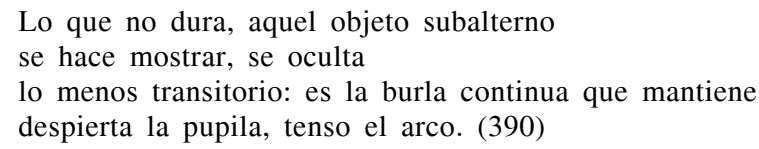

En su sintaxis y sus imágenes la poesía de Aníbal Núñez se revela aguda y filosa, perfecta y quebradiza. Expone los mecanismos del engaño indivi-

${ }^{6}$ Aníbal Núñez fue, además de poeta, un destacado artista plástico. La mayor parte del poemario Figura en un paisaje $(1974,1992,1993)$ fue estructurado a partir de cuadros famosos (de Botticelli, Durero y otros), al modo de una colección o pequeño museo personal. La influencia de la pintura en la poesía de Núñez y su «plasmación plástica de la palabra» fueron abordadas por Ruiz Casanova (1997). 
dual y colectivo e invita a pensar más allá de los piadosos cristales. Vuelve sobre la mirada desnuda y herida, un acicate que recuerda el ardor de estar vivos.

El fenómeno de reflexión se produce cuando un rayo de luz se refleja en una superficie pulida. Este principio se aplica en los espejos, que tienen la característica de reconstruir una imagen simétrica al objeto que reflejan. La imagen especular no llega a ser un signo icónico porque no representa una cosa ausente, pero constituye sin duda un fenómeno presemiótico que nos sitúa frente al problema de lo real y lo virtual (Eco 1999: 420-27). El sujeto poético de los textos de Núñez reconoce «que la figura de uno en el espejo / piensa de otra manera» (262) y ve en Narciso una víctima de la trampa cristalina:

$$
\begin{aligned}
& \text { Qué culpa tuvo aquél de que del otro } \\
& \text { lado se prolongase su sed, qué culpa tuvo } \\
& \text { de enamorarse de su simetría. (206) }
\end{aligned}
$$

Cuando un rayo de luz encuentra la superficie de separación entre dos medios transparentes, se quiebra o refracta. Los efectos de refracción se basan en el hecho de que la luz viaja más despacio en un medio más denso. Así ocurre en el agua, puesto que «luego el que la ve todo confunde»: la corriente «muestra su cristal» y el agua fluye «inseparable / de cómo en otra onda se desdice» (270-71).

Dada «la incomunicabilidad de un fenómeno óptico» (262), para Núñez la multiplicación de las imágenes delata el alcance limitado y parcial de la percepción humana. En torno de esta cuestión se estructura Cuarzo (1981, 1988), el libro que signa la madurez definitiva de la voz poética. Con respecto a la imagen que da título al poemario, F. Freire Jorge señaló que «Cuarzo quería ser, en la voluntad del poeta ..., una manera de cristalizar la materia que presenta seis caras o facetas; un libro estructurado en seis partes» (1987: 295). Según Miguel Casado, se trata de un «libro eje, espacio de cruces y definición de temas, tonos y paisajes» (1999: 151). En él conviven los diferentes hilos que conforman la trama poética del salmantino: el poema metatextual, los motivos de la pintura y la mitología grecolatina, el elogio de la naturaleza y el azar, la fascinación por la ruina.

El poema final se titula «Cuarzo» y constituye un apóstrofe al mineral. Allí se alude al aspecto huidizo y refractario de la luz, que «es muda, / choca y vuelve, / deja inocuo color en sus obstáculos; / o se aloja» (320). Cerca tal vez del Fiat lux cosmogónico, para Núñez la diversidad del mundo surge del paso de la luz por las cosas. Sin embargo toda imagen es parcial, y el mineral transparente pone en evidencia el desamparo y la vacilación del sujeto:

$$
\begin{aligned}
& \text {... Oh, cuarzo, } \\
& \text { exime a tus aristas del tacto aquel del hijo }
\end{aligned}
$$




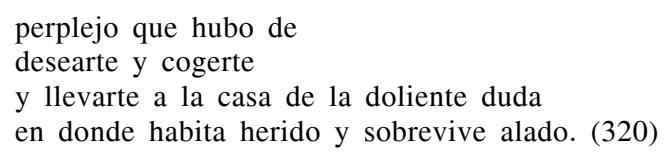

Las múltiples caras del cristal convocan los diferentes puntos de vista para expresar la complejidad de los seres y los sucesos. Un lema fundamental de la poesía de Núñez es aquel que se encuentra en sus dos versos tan citados: «No se agota / la forma en una sola visión» (362). Toda percepción es limitada frente a la vastedad inasible del mundo. El perspectivismo surge como metáfora del campo visual pero se hace extensivo a todas las áreas del conocimiento y la conducta humana, pues «distintas / luces cuentan la historia de distinta manera» (235).

El imaginario del cristal en los textos poéticos de Núñez guarda una íntima relación con el «modelo óptico de la percepción y de la geometría de la percepción» que Gilles Deleuze identificó en la filosofía de Leibniz y la estética barroca (1998: 33). Todo el pensamiento estético del filósofo francés se juega entre los dos infinitos del cristal, la microscopia del afecto y la macroscopia del mundo, «en el movimiento que va de los elementos del cristal al proceso de cristalización, y después a los estados cristalinos». Es posible rastrear un antecedente de la imagen deleuziana en las teorías del alemán Wilhelm Worringer, quien habló de la «belleza cristalina» que se produce cuando en el arte no rige la imitación de la naturaleza (Buci-Glucksmann 2003: 110-11).

Así como las pirámides ponen en evidencia una cristalización egipcia, y las catedrales góticas una cristalización trascendental, por nuestra parte advertimos que también en la poesía de Núñez el cristal funciona como un lente que aumenta el estatuto de la abstracción. Y en los textos del salmantino las tres caras de la abstracción - mineral, geométrica y arquitectónica- están directamente asociadas con el hermetismo entendido en ambos sentidos del término. Veamos dos citas textuales que aclaran esta idea. Por un lado, la presencia ubicua del cristal acompaña en innumerables escenas que se remontan a un espacio atemporal y descontextualizado:

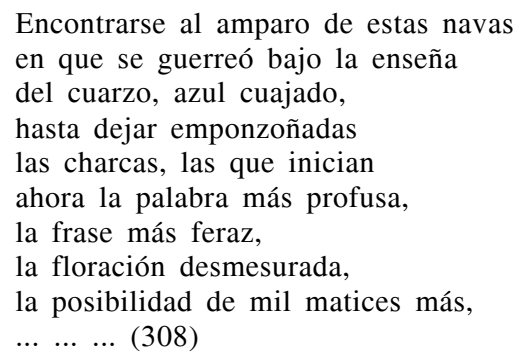

El poema incluye el arcaísmo «nava», que designa a una tierra llana, sin árboles, generalmente situada entre montañas. Este campo de batalla 
innominado e imposible de ubicar referencialmente es uno de los tantos elementos que confluyen en el hermetismo como estrategia literaria utilizada por Núñez. En uno de sus poemarios el autor se declaró conciente de la «apariencia hermética» de sus textos (1995: 243), y no es difícil hallar en toda su obra claros indicios de una filiación con Mallarmé. Por otro lado, versos como aquellos con los que comienza un ya citado poema ( «Cuarzo de seis pasajes / y seis del cielo, hollado / por los que distribuyen signos», 320) remiten al hermetismo alquímico, la tradición milenaria que sigue los libros atribuidos al filósofo egipcio Hermes, que se supone vivió en el siglo XX antes de Jesucristo7.

Hermética en los dos sentidos de la palabra, la imagen cristalina adquiere aun otra significación en la poesía de Aníbal Núñez. Escribió Roland Barthes que «la piedra no es la vida ni la muerte, es la inercia, la terquedad de la cosa por no ser más que ella misma: es lo inmóvil infinito» (2003: 65). Por su condición mineral, el cristal habla también de lo que no cambia ni se consume:

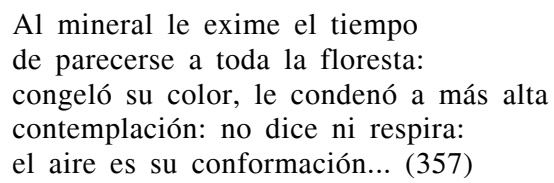

La inmovilidad de la roca y el cristal nos enfrenta con el problema del tiempo, cuestión que fue específicamente abordada por Deleuze en sus estudios sobre cine $^{8}$. Ante todo la imagen-cristal expresa una dualidad, pues a toda imagen actual (que consiste en la percepción de los objetos reales) le corresponde una imagen virtual como un doble o reflejo (1996: 97).

${ }^{7}$ En la «Nota Preliminar» a «Reconstrucción del laberinto», la Sección II de Clave de los tres reinos, el autor menciona la correlación entre dos series numeradas de poemas y luego agrega que prefirió ahorrar «otras claves» al lector «para que prevalezca esa apariencia hermética y a él le quepa su propia reconstrucción» (243). Es un homenaje a Mallarmé el poema «Las de l'amer travail», incluido en la Sección III de Cuarzo, que menciona al «decorador de tazas chino, / que Stéphane figuró» (396). Respecto de otro poemario, Primavera soluble, sostiene Miguel Casado que «la impresión de hermetismo procede del lector, de su deseo inconsciente de reconstruir el relato no escrito; pero si acepta entregarse a la voluntad más alta del poema, las frases restallan con perfil absoluto» (1999: 137). Coincido plenamente con este autor en que el hermetismo de Núñez no es asimilable a «una vacuidad abstracta y preciosista» ni a «una falta de sentido o un arabesco inútil» (193). Por su parte Penélope Casado (2005) ha llamado la atención sobre la enorme cantidad de motivos y arquetipos provenientes de la tradición hermética en la obra de Núñez. Entre ellos se destacan algunos personajes (el hechicero o alquimista, Narciso, Icaro) y determinados símbolos (el azufre, el tarot, Saturno, la puerta, los presagios, la semilla, el círculo).

8 «Los cristales del tiempo», capítulo 2 de La imagen-tiempo. Estudios sobre cine 2, Barcelona, Paidós, 1996, pp. 97-133. 
Siguiendo el razonamiento de Bergson, afirma Deleuze que lo actual es siempre un presente, y la imagen, por tanto, es presente y pasada al mismo tiempo: «El presente es la imagen actual, y $s u$ pasado contemporáneo es la imagen virtual, la imagen en espejo» (111).

La imagen virtual (recuerdo puro) no es un estado psicológico o una conciencia: existe fuera de la conciencia, en el tiempo. De modo que la imagen cristalina pone de manifiesto la operación más fundamental del tiempo, que se desdobla a cada instante en presente y pasado, diferentes uno y otro por naturaleza: «La imagen-cristal es el punto de indiscernibilidad de las dos imágenes distintas, la actual y la virtual, mientras que lo que se ve en el cristal es el tiempo en persona, un poco de tiempo en estado puro, la distinción incluso entre las dos imágenes que no acaba de reconstituirse» (114-15).

La mención del «tiempo puro» nos remite al análisis de la ruina desarrollado por Marc Augé. Evidentemente la profusión de ruinas y cristales en los textos líricos de Aníbal Núñez es indicio de una preocupación constante por el tiempo, en su dimensión objetiva y subjetiva $a^{9}$. El devenir temporal es más que un tópico recurrente, es un problema medular que surge a propósito de todos los temas que aborda la poesía del salmantino: la reflexión metalingüística y estética, el conocimiento y la historia, las trampas de los sistemas ideológicos, los viajes, el amor, la amistad.

Parafraseando a Deleuze, podemos afirmar que los cristales de Núñez exhiben el fundamento oculto del tiempo, es decir, su diferenciación en dos chorros, el de los presentes que pasan y el de los pasados que se conservan. El cristal es una ratio cognoscendi del tiempo, y el tiempo, inversamente, es ratio essendi (135). Las dimensiones heurísticas y estéticas de la imagen cristalina, múltiple por naturaleza, son infinitas. Surge naturalmente un paralelismo entre las escenas cinematográficas de Ophuls, Renoir, Fellini y Visconti analizadas por Deleuze y los aspectos arriba señalados de la poesía de Aníbal Núñez. También ésta se nos presenta sintáctica y estructuralmente como un cristal perfecto, sin un afuera, donde prima la teatralidad (Puppo 2004b), o bien como un cristal astillado (palacio trunco, naturaleza vencida), con un punto de fuga. El cristal infinito, en expansión, multiplica los puntos de vista y las versiones, en tanto que el cristal sintético (de los aristócratas y los emisarios del progreso, de las instituciones vaciadas de simbolismo) se vuelve opaco por descomposición.

\footnotetext{
9 Afirma Deleuze: «Lo actual es siempre objetivo, pero lo virtual es lo subjetivo» (1996: 115).
} 


\title{
4. POEMA Y EXPERIENCIA DEL TIEMPO. CONCLUSIONES
}

No nos hemos detenido mayormente aquí en los prodigios formales que presentan los textos de Aníbal Núñez: no hemos buscado las causas de su musicalidad extraña, que anida tal vez en el quiebre de la frase y la oración, en la acumulación de los sintagmas, o en el aislamiento de ciertas palabras. Tampoco hemos ahondado en el concepto de belleza como el instante terrible y supremo en que la vida sale al encuentro del ser humano (en el amor, las olas, la melodía, la mariposa o el poema). En cambio hemos seguido el rastro de dos imágenes nucleares, la ruina y el cristal, y ellas nos han permitido trazar un mapa de los tópicos, las tradiciones y los problemas que confluyen en una obra de profundas densidades semánticas, donde no existen significados fijos y donde el lector está llamado a participar activamente. Al cabo de nuestro itinerario hermenéutico no podemos sino reconocer el dinamismo de las imágenes, tal como fue señalado por Joël Thomas:

\begin{abstract}
La imagen simbólica es fundamentalmente relación entre macrocosmos y microcosmos, entre un campo del imaginario y 'tarjetas postales' particulares de este vasto paisaje, que corresponden a nuestros sistemas particulares de representación. Así pues, el imaginario es fundamentalmente dinámico, puesto que es una circulación constante entre formas y fuerzas: imágenes formadoras en busca de un soporte encarnado, y representaciones, 'tarjetas postales' del mundo hechas por nuestra psiquis, y en busca de un sentido que les permita escapar al solipsismo. (1998: 161)
\end{abstract}

Retomando las hipótesis finales a las que nos condujo el análisis, es preciso concluir que las imágenes de las ruinas y los cristales en la obra de Núñez se vinculan con una poética del tiempo subterránea pero coherente, diseminada en los sucesivos poemarios.

Hay diferentes dimensiones temporales o maneras de representar el tiempo en los textos del salmantino. Una primera faceta es la que se refiere al tiempo de la naturaleza, que se manifiesta como un ritmo implacable pero sabio, pautado por los cambios del día a la noche y la sucesión de los meses y las estaciones. Esta armonía del planeta y el universo es ajena a la voluntad y la conciencia de los seres humanos, de ahí que sea vano todo «inútil calendario» (96). Se trata del «tiempo cósmico», aquel que reconocemos como propio de los textos medievales y cuya cristalización literaria se encuentra en el Libro de Buen Amor. Sofía Carrizo Rueda (2001) ha reinterpretado la tríada tiempo-muerte-fiesta en cuanto garante de la «coherencia semántica» en el texto bajomedieval. Sorprendentemente, una «coherencia semántica» de rasgos similares se aprecia en la poética de Aníbal Núñez. Los fenómenos atmosféricos — la nieve o la lluvia- tienen la función de recordar la magnitud de los ciclos naturales, y ante esa grandeza 
el sujeto poético proclama sus «bodas con la intemperie» (310). El tiempo de la naturaleza guarda un misterio y un sabor nostálgico para el sujeto que lo añora: «La vida / será un largo collar de atardeceres, / coral teñido de dolor» (272).

En contraste con el ritmo natural, anterior a la conformación de las ciudades modernas, surge el tiempo fragmentado de los hombres y las mujeres, incapaces de percibir la historia como un continuum que dota de sentido el momento presente. El análisis de la imagen de la ruina demostró que dicho espacio sólo alberga retazos de otro tiempo, pues «todo lo transitorio allí es vigente» (244). Arrojado al fin del siglo veinte y en un presente de la enunciación sin ideologías ni grandes mitologías donde aferrarse, el palacio abandonado es un «irónico emblema de la supervivencia» (254), apenas una «escena del pasado muerto» (258). Justamente esa falta de perspectiva histórica barre con toda trascendencia o sentido metafísico que se le quiera dar a la imagen decadente: el esplendor de antaño ya no se recuerda o no le interesa a nadie; en el mejor de los casos los dueños actuales conservan la casa como una herencia de alcurnia; mientras todos corren tras el dinero, nadie aporta libros o lee en la biblioteca (334).

Esta dimensión fragmentaria del tiempo se relaciona con tres estrategias discursivas presentes en los poemas, el anacronismo, el anclaje histórico y la intemporalidad. Ejemplo de anacronismo es la aparición del fantasma, «ese señor antiguo, subalterno del tiempo,» que a fines del siglo veinte asoma tras los cristales vestido «de aldeano y truhán, de caballero» (329). Llamamos anclaje histórico a la estrategia de los poemas que abren el espacio de représentance o lieutenance propio del discurso historiográfico y de los textos que presentan el entrecruzamiento de historia y ficción (Ricœur 1985: 329). Son numerosísimos los poemas de Núñez que se sitúan en una mítica Antigüedad grecolatina, llena de presagios, o bien en el siglo XVIII de las telas de Watteau y Fragonard, «cuando ya se han marchado los cortesanos» (96). Sin duda el caso más paradigmático de pastiche histórico lo constituye el poemario Estampas de ultramar, construido en su totalidad como «estampas» o fragmentos de un relato de viaje del siglo XIX. En contrapartida, como ya lo hemos adelantado, la intemporalidad contribuye a la apariencia hermética de secciones enteras de poemarios como Clave de los tres reinos o Cuarzo. En el marco de estas tres estrategias del discurso, la imagen del cristal complementa los juegos temporales de dobles y espejos, en tanto que marca la distancia del sujeto frente a lo descrito y multiplica los puntos de vista.

Otra faceta que exploran los textos de Aníbal Núñez, tan evidente como las anteriores, es el pathos del tiempo, es decir, la dolorosa captación humana del devenir temporal que todo lo atraviesa y lo desgasta. En este sentido juegan un rol fundamental los deícticos (ayer, hoy) y los tiempos verbales (Pretéritos y Presente de Indicativo) para establecer un contrapunto 
entre el pasado del enunciado y el presente de la enunciación. La experiencia del paso de tiempo como aniquilación de todo lo viviente o lo erigido se expresa en imágenes de alcance inédito como la flor caída sobre la hierba o el tronco sometido al hacha, ambos víctimas de «la Industria de la Profanación» (115). Esa guerra contra el tiempo el poeta la sabe perdida, por eso en los últimos libros se entrega cada vez más sumisamente a su dominio: «No limpiéis esas piedras; / que sean del liquen ya» (370).

Por otra parte en los últimos libros de Núñez hay una conciencia del desdoblamiento del instante en la imagen pasada y la presente. La existencia virtual del pasado, señalada por Bergson y asociada por Deleuze a las imágenes cristalinas, surge en los textos poéticos como una barrera que se interpone a la mirada. «Ya basta con lo visto» (388), pues frente a lo nuevo proyectamos siempre nuestro pasado, «aquello / que construye el deseo / como un pesado espejo que nos cierra el camino» (389). El exceso de imágenes percibidas anteriormente conduce a una «pobreza» por «acumulación de escasa fantasía» (388) donde parece imposible el olvido: «Demasiado lo visto para no recordarlo» (389).

Esa simultaneidad de pasado y presente en el plano temporal coincide con la concentración cifrada - hermética y geométricamente- del espacio. La poesía de Núñez logra «temporalizar el espacio y espacializar el tiempo» (Rodríguez de la Flor 1997: 9). En el ámbito de la ruina, así como en el de la ciudad vista como un gran edificio amurallado, conviven los distintos estratos del tiempo sin que se establezca una relación causal directa entre ellos. Imagen actual e imagen pasada-virtual son dos caras de un mismo cristal, como la cercanía y la distancia o como el recuerdo y el olvido. La arquitectura compleja y la multiplicidad de formas en cadena remiten a los azares cristalinos, capaces de unir elementos diversos en nuevas unidades significantes. Ante el ardor genuino de los ojos, «crisálidas tiernas» (390), se interpone siempre la conciencia del ver y el peso de lo ya visto. Más allá de que el lente sea transparente, opaco o de aumento, la presencia mediadora de los cristales pone de manifiesto la superposición de los códigos simbólicos, históricos y culturales.

Ya advertimos que en la poesía de Núñez se manifiesta una última posibilidad de concebir el tiempo, ligada también a las imágenes de la ruina y el cristal. Se trata de la experiencia del tiempo puro, que se articula como una abstracción mental (pensar el tiempo fuera del tiempo) pero principalmente como una vivencia extraordinaria del sujeto poético (toparse con el tiempo, sentirse fuera de él). En numerosos textos de Núñez el nolugar de la ruina provoca la irrupción en un tiempo distinto y no mensurable por los relojes. Ese no-tiempo aparece como la suma de todos los tiempos, en el cual «algo va a ocurrir» equivale a «ha ocurrido algo» (348). En este sentido, el doble de la ruina es la «casa inacabada» (181), pues también respecto a ella se puede decir que «todo aquí se inicia» (324). 
La experiencia del tiempo puro es posible cuando el espacio está habitado por «mil silencios» (252) que callan otras voces como las del egoísmo, el materialismo o el deseo. Es el tiempo de la contemplación, que se produce cuando el sujeto se entrega a la belleza del arte (una pintura, una ruina) o de la naturaleza (un paisaje al atardecer). Ese instante de plenitud es propicio para el advenimiento (170,347), palabra clave en la poesía de Núñez y equiparable a la epifanía de Joyce. ¿Qué adviene o se revela? Tal vez «la quemadura que abre el conocimiento», la posibilidad de «contemplar la dureza que alarga el pensamiento ... / en la contemplación de opuestos símbolos» (386).

En un universo poético donde no existe el amparo de la divinidad ni la fe en el resto de los hombres, el único tiempo de revelación o de felicidad plena se produce al contemplar lo bello (artificial o natural) y al mirar a la amada «alegre / y viva» (175). Sin embargo esos instantes privilegiados son pocos y, por supuesto, fugaces. Más que concreción, la experiencia del tiempo puro es un anhelo ${ }^{10}$. El sujeto poético sueña con la pura contemplación que «sería mirar, hacer, ser hecho, respirar luz y aire» (373). Sólo entonces se haría realidad el deseo de «mirar al cielo sin afán» (386), es decir, prescindiendo del filtro de los cristales.

La contemplación gozosa provoca la existencia del poema, que da cuenta de ese momento privilegiado que se ha vivido. Pero allí encuentra también su límite la escritura, porque en definitiva el lenguaje es código, símbolo, mediación, y «la hermosura / niega la voz que intenta proclamarla» (348). El poema habla del advenimiento, pero la belleza no se deja capturar en la escritura. El sujeto poético en los textos de Aníbal Núñez afirma su preferencia por la libertad del azar frente al orden opresor del lenguaje, pero sin embargo modela tenazmente, cuestiona y rehace la forma de sus versos. Afirma a coro con Roland Barthes que «escribir no es vivir» (280), aunque él mismo apela a su «razón / de estar aquí siguiendo» (363). Esta aporía del poema (Casado 1999: 94) resume la paradoja de tantos otros poetas del siglo veinte, para quienes la palabra es un imperativo vital que conduce a la experiencia del límite y la derrota ${ }^{11}$.

De las «pupilas incendiadas» a la «palabra encendida» (309): tal es el trayecto de la imagen, primero forma de la percepción, luego recuerdo o

\footnotetext{
${ }^{10}$ La de Núñez es una poesía de advenimiento y de anunciación $(348,349)$, donde también son frecuentes los adioses y las despedidas (272, 307, 319). El sujeto poético articula su palabra desde el compás de la espera $(176,198,362)$ y la promesa: «vendremos» (362).

${ }^{11}$ Es posible colegir que la aporía del poema en Núnez expresa «una nueva conciencia poética» posterior a la tendencia autorreferencial de las vanguardias: «la de comprender no sólo los límites del lenguaje poético en relación con la realidad (incluyendo dentro del concepto los límites con lo real social) sino también, y esto es importante, la relación del lenguaje poético consigo mismo, los límites de ese canto a su propia inaccesibilidad» (Milán 2001: 119).
} 
proyección imaginaria, finalmente devenida lenguaje e imagen poética. Lejos de erigirse como rocas macizas, arrojadas contra los edificios del sentido, los textos de Aníbal Núñez se alzan como ruinas cristalinas, compuestas con ironía o dolor a partir de los despojos clásicos, medievales, barrocos, románticos y decadentes. Las distintas capas del pasado se articulan con las múltiples posibilidades del presente y el futuro, en una sucesión de luces, matices y reflejos. Hay algo terrible en toda contemplación, porque tras ella sólo queda la memoria de la visión fugaz, el aquí y ahora de la mirada imperfecta. Sin embargo, el poema es nuevamente ardor o fuego, y

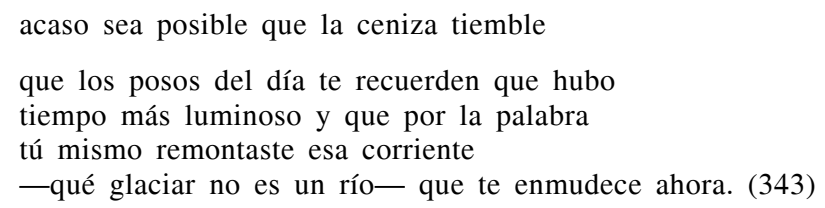

Pese a todo la palabra poética permite acceder a ese «tiempo más luminoso» donde no se precisan más razones ni... palabras. La experiencia del tiempo puro ocurre en el poema, que es fuego y también agua, río que se ha vuelto hielo, glaciar, cadena de cristales.

\section{BIBLIOGRAFÍA CITADA}

AA.VV., «Aníbal Núñez (1944-1987)», Pliegos de poesía Hiperión 5-6, verano 1987. AUGÉ, Marc, El tiempo en ruinas, Barcelona, Gedisa, 2003.

Auden, W. H. and Holmes PeArson, Norman (editors), The Portable Romantic Poets: Blake to Poe, New York and London, Penguin Books, 1978.

Bajtin, Mijail, Poétique de Dostoievski, Paris, Seuil, 1970.

BARTHES, Roland, «De la joya a la bisutería» (1961), en Acta poética, Número 24-1, Primavera 2003, pp. 63-70.

Benjamin, Walter, «Allegory and Trauerspiel», en The Origins of German Tragic Dra$m a$, Londres, Verso, 1998.

BREnNAN, Thomas J., «Wordsworth's 'Tintern Abbey'», Explicator, 2004 Fall, 63 (1), pp. 13-15.

BuCI-GlucksmanN, Christine, «Os cristais da arte: uma estética do virtual», en Revista de comunicaçao e linguagens 31, Imagem e vida, Universidade Nova de Lisboa, 2003, pp. 107-22.

Burgos, Jean, Pour une Poétique de l' imaginaire, Paris, Seuil, 1982.

CARrizo RUEDA, Sofía, «Una relectura de la tríada «tiempo-muerte-fiesta» en el Libro de Buen Amor desde las teorías del imaginario poético», en Studia in honorem Germán Orduna, Alcalá de Henares, Universidad de Alcalá, 2001, pp. 163-79.

CASAdo, Miguel, La puerta azul. Las poéticas de Aníbal Núñez, Madrid, Hiperión, 1999.

CASAdo, Penélope, "Aníbal Núñez en la tradición hermética», en Letras de Deusto, Volumen 35, Número 108, 2005, pp. 159-176.

Ciplijauskaité, Biruté, «Alzarse de la ruina», en Sibbald, K. M., Fuente, R. de la y Díaz, J. (eds.), Ciudades vivas/ciudades muertas: Espacios urbanos en la literatura y el folklore hispánicos, Valladolid, Universitas Castellae, 1999, pp. 57-68. 
CiRlot, Juan-Eduardo, Diccionario de símbolos, Barcelona, Labor, 1969.

Deleuze, Gilles, La imagen-tiempo. Estudios sobre cine 2, Barcelona, Paidós, 1996. —, El pliegue. Leibniz y el Barroco, Barcelona, Piados, 1998.

DESHOULIÈRES, Valérie-Angélique (ed. e introd.), Vacher, Pascal (ed., introd., y bibliografía), La Mémoire en ruines: Le Modèle archéologique dans l'imaginaire moderne et contemporain, Clermont-Ferrand, Centre de Recherches sur les Littératures Modernes et Contemporaines, Université Blaise Pascal, 2000.

DURAND, Gilbert, Les Structures anthropologiques de l'imaginaire. Introduction à l'archétypologie générale, Paris, Dunod, 1993. [1a. ed. 1960]

ECO, Umberto, Kant y el ornitorrinco, Barcelona, Lumen, 1999.

FERRI COLL, José María, «Ciudades dormidas. El ensueño de las ruinas en la poesía española del Siglo de Oro», en Rovira, José Carlos (ed. e introd.), Escrituras de la Ciudad, Madrid, Palas Atenea, 1999, pp. 47-74.

Freire Jorge, Francisco José, Prólogo a Cuarzo [1987], en Aníbal Núñez, Obra, poética (edición de Fernando R. de la Flor y Esteban Pujals Gesalí), Madrid, Hiperión, 1995, t. I, pp. 294-96.

Helfer, Rebeca, «The Death of the 'New Poete': Virgilian Ruin and Ciceronian Recollection in Spenser's The Shepheardes Calender», Renaissance Quarterly, 2003 Autumn; 56 (3), pp. 723-56.

KenNEDY, Deborah, «Wordsworth, Turner, and the Power of Tintern Abbey», Wordsworth Circle, 2002 Spring; 33 (2), pp. 79-84.

LARA GARRIDO, José, «Notas sobre la poética de ruinas en el Barroco», Analecta Malacitana III (1980).

LÉvY, Maurice, «Les Ruines dans l'art et l'écriture: Esthétique et idéologie», Bulletin de la Societé d'Etudes Anglo-Americaines des XVIIe et XVIIIe Siecles, 1981 Nov., 13, pp. 141-58.

LiuzzA, R. M., «The Tower of Babel: The Wanderer and the Ruins of History», Studies in the Literary Imagination, 2003 Spring; 36 (1), pp. 1-35.

LÓPEZ BUENo, Begoña, «Tópica literaria y realización textual: Unas notas sobre la poesía de las ruinas en los siglos de oro», Ideologies and Literature: Journal of Hispanic and Lusophone Discourse Analysis, 1988 Spring; 3 (1), pp. 129-48.

MCHALE, Brian, «Archaeologies of Knowledge: Hill's Middens, Heaney's Bogs, Schwerner's Tablets», New Literary History 30 (1), 1999, pp. 239-62.

MILÁN, Eduardo, «En su ausencia: tres notas sobre poesía», en Solares, Blanca (Coord..), Los lenguajes del símbolo. Investigaciones de hermenéutica simbólica, Barcelona, Anthropos, 2001, pp. 118-24.

Nicolás, César, «Poesía y recepción. El caso de Aníbal Núñez», en Insula 606 (VI 1997), pp. 9-12.

NúÑEZ, Aníbal, 29 poemas (en colaboración con Angel Sánchez), Salamanca, Vitor, 1967.

—, Fábulas domésticas, Barcelona, Ocnos, 1972.

—, Cuarzo, Madrid, Libros de la Ventura, 1981. Edic. definitiva, 1988.

—, Trino en estanque, Madrid, Cuadernillos de Madrid, 1982.

—, Alzado de la ruina, Madrid, Hiperión, 1983.

—, Estampas de ultramar, Valencia, Pre-Textos, 1986.

-, Clave de los tres reinos, Badajoz, Editora Regional de Extremadura, 1986.

—, Cristal de Lorena, Málaga, Newman / Poesía, 1987.

-, Casa sin terminar, Mérida, La Centena, 1991.

—, Primavera soluble, Valencia, Pre-Textos, 1992.

-, Memoria de la casa sin mención al tesoro ni a su leyenda antigua, Mérida, Espacio / Espaço Escrito, 1992. 
—, Figura en un paisaje, Salamanca, Diputación de Salamanca, 1993.

-, Obra poética I y II (edición de Fernando R. de la Flor y Esteban Pujals Gesalí), Madrid, Hiperión, 1995.

PARDO PASTOR, Jordi, «La 'poesía de ruinas' en el primer Lope», en Espéculo. Revista de estudios literarios, Marzo-junio 2002, 20, s/n.

PARRINDER, Patrick, «The Ruined Futures of British Science Fiction», en Leader, Zachary (ed.); On Modern British Fiction, Oxford, Oxford UP, 2002.

ProfETI, Maria Grazia, "YYo vi la grande y alta jerarquía': El tema de las ruinas en Quevedo», en Criticón, 2003, 87-89, pp. 709-18.

PuPPO, María Lucía, «La naturaleza como tópico y alegoría en la poesía de Aníbal Núñez». En Actas del II Congreso Internacional Celehis de Literatura, Universidad Nacional de Mar del Plata, 2004a [En prensa].

—, «La teatralidad del poema: una lectura de Aníbal Núñez», en Actas de las Segundas Jornadas Diálogos entre Literatura, Estética y Teología, Universidad Católica Argentina, 2004b, CD Rom s/n de pág.

—, «Arquitecturas del poema: Carl Phillips y Aníbal Núñez», en Actas de las II Jornadas Internacionales de Literaturas en Lenguas Extranjeras «Perspectivas literarias desde el umbral del tercer milenio», Universidad Católica Argentina, 2005 [En prensa].

REIJEN, Willem van, «Labyrinth and Ruin: The Return of the Baroque in Postmodernity», Theory, Culture \& Society, 1992 Nov, 9 (4), pp. 1-26.

RICEUR, Paul, Temps et récit III. Le temps raconté, Paris, Seuil, 1985.

RODRÍGUEZ DE LA FLOR, Fernando, «Medido, pesado y contado», en AA.VV., «Aníbal Núñez (1944-1987)», Pliegos de poesía Hiperión 5-6, verano 1987.

—, «Aníbal Núñez: el desmontaje impío de la ficción poética», en Insula 606 (VI 1997), pp. 7-9.

Ruiz Casanova, José Francisco, «Sintaxis tridimensional», en Insula 606 (VI 1997), pp. 13-14.

SAID, Edward W., El mundo, el texto y el crítico, Buenos Aires, Debate, 2004.

SiEGMUND, Andrea, Die romantische Ruine im Landschaftsgarten: Ein Beitrag zum Verhältnis der Romantik zu Barock und Klassik, Würzburg, Königshausen \& Neumann, 2002.

THOMAS, Joël, «L'imaginaire et les autres concepts opératoires (systémique, complexité)», en Introduction aux méthodologies de l'imaginaire, Paris, Ellipses, J. Tomas (dir.), 1998.

THOMAs, Sophie, «Assembling History: Fragments and Ruins», European Romantic Review, 2003 June; 14 (2), pp. 177-86.

VAlente, José Angel, El diamante y la ternura, Segovia, Pavesas, 1994.

WAJCMAN, Gérard, «El arte, el psicoanálisis, el siglo», en AA.VV., Lacan. El escrito, la imagen, Buenos Aires, Ediciones Del Cifrado, 2004.

Wiedmann, August, Romantic Art Theories, London, Gresham Books, 1986.

Williams, Raymond, El campo y la ciudad, Barcelona, Piados, 2001 [Orig. 1973].

ZnOJEMSKÁ, Helena, «'The Ruin': A Reading of the Old English Poem», Litteraria Pragensia: Studies in Literature and Culture, 1998, 8 (15), pp. 15-33. 